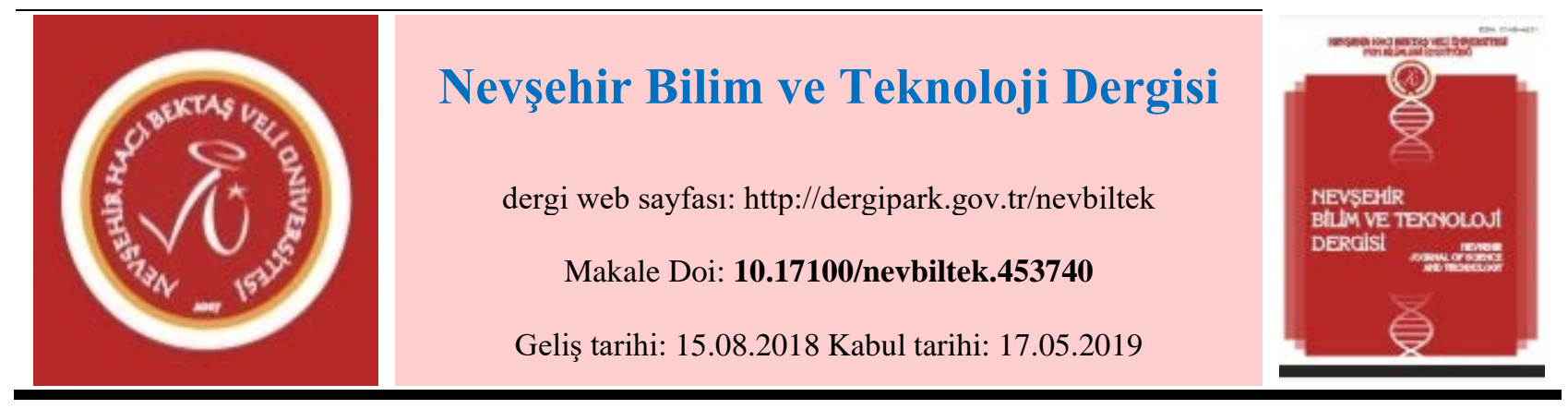

\title{
Şantuklu İplik Özellikleri 1
}

\author{
Nilgün ÖZDILL ${ }^{1}$, Gonca ÖZÇELIKK KAYSERİ², Gamze SÜPÜREN MENGÜÇ3 \\ 1 Ege Üniversitesi , Mühendislik Fakültesi Tekstil Mühendisliği Bölümü, İzmir, Türkiye \\ ORCID ID:0000-0001-9488-5337 \\ 2 Ege Üniversitesi, Emel Akın Meslek Yüksekokulu, İzmir, Türkiye \\ ORCID ID:0000-0001-6775-8295 \\ 3 Ege Üniversitesi, Emel Akın Meslek Yüksekokulu, İzmir, Türkiye \\ ORCID ID:0000-0002-2786-7283
}

Öz

Eğirme alanındaki gelişmelerle birlikte, farklı alan ve son kullanımlar için birçok iplik yapısı oluşturulmuştur. Şantuklu iplik, eğirme işlemi sırasında iplik lineer yoğunluğunun değiştirilmesiyle şantuk görünüşünün elde edildiği ve özel görünümü nedeniyle çeşitli giysilerde yaygın olarak kullanılan bir çeşit fantezi ipliktir. Şantuk iplik yapısı iplik üreticilerine standart ürünler yerine üretildiğinde rekabet avantajı ve ekonomik fayda sağlarken, müşteriler için de daha iyi bir dekoratif etki sağlama olanağı sunmaktadır. Şantuk ipliklerinin belirleyici özelliği, yapısındaki ipliğin uzunluğu boyunca aralıklı olarak değişen boyutlardaki düzensizliklerin kasıtlı oluşturulmasıdır. Kalınlık, uzunluk ve şantuk aralıklarının değişmesinin verdiği efektlerle giysilik amacıyla özellikle denim olmak üzere dokuma ve örme kumaşlarda ve ayrıca perde, döşemelik gibi ev tekstillerinde kullanılmaktadır. Şantukların büyüklüğü (uzunluk, çap, şekil), tekrarlama aralığı, renk ve lif tipi değişebilir. Basit bir şantuk ipliği yapısı, zemin kısmı ve şantuk kısmı olmak üzere iki bölümden oluşmaktadır. Şantuk ipliğinin görünümü, her bir bileşen parçasının uzunluğu ve doğrusal yoğunluğundan etkilenir. Şantuk iplikleri yapısal olarak basit şantuk, değişken numaralı, değişken bükümlü ve çok bileşenli olarak ayrılırlar. Bu çalışmada şantuk iplikleri tanttılacak ve şantuk iplikleri için tanımlanması zor olan kalite kontrol parametreleri tartışılacaktır.

Anahtar kelimeler: Şantuklu iplik, şantuk efekti, iplik karakteristikleri, kalite kontrol

\section{Characteristics of the Slub Yarns}

\begin{abstract}
Developments in spinning have generated many yarns structures intend for different domains and end use. Slub-yarn is a kind of fancy yarn, whose slub appearance is gained via the variation of the yarn linear density during the spinning process, and because of its special appearance, has been widely used in a variety of garments. Slub yarn structure is beneficial economically for yarn manufacturers that find it difficult to compete in standard products and also for the customer who find a decorative effect and a better texture imparted to the product. The decisive feature of slub yarns is the deliberate formation of irregularities in varying dimensions, repeatedly spaced along the length of the yarn in the structure. The variation of thickness, length and pause gives a wide range of effects, ensuring the use of slub yarns in many applications like denim, shirting, knitwear, casualwear, ladies dress material and also in curtains and upholstery. The size of the slubs (length, diameter, shape), repetition interval, color and fiber type may vary. A simple slub yarn structure is composed of two parts, the base part and the slub part. The appearance of slub yarn is influenced by the length and linear density of each constituent part. Structurally slub yarns can be divided as: basic slubs, multicount, multi-twist and combinations of multicount \& multi-twist. In this paper slub yarns will be introduced and quality control parameters which are difficult to define for slub yarns will be discussed.
\end{abstract}

Key words: Slub yarn, slub effect, yarn characteristics, quality control

\footnotetext{
${ }^{1} \mathrm{Bu}$ çalışma I. Uluslararası Teknololoji Bilimleri ve Tasarım Sempozyumu (ITESDES)-Giresun’da poster/özet bildiri olarak sunulmuştur.
}

Sorumlu yazar e-mail: nilgun.ozdil@ege.edu.tr 


\section{Giriş}

Ticari olarak üretilen ipliklerin büyük kısmı iplik boyunca renk ve doğrusal yoğunluk açısından düzgünlük gösteren düz ipliklerdir. Tekstilciler için renk ve yapı bakımından mükemmel düzgünlük sağlayan iplikler elde etmek yüzyıllardır teknik araştırma ve yeniliklerin ana amacı olmuştur [1,2]. Ancak globalleşme ve dünyada birçok sektörde olduğu gibi tekstil ve hazır giyim alanında da küresel rekabetin artışı kaliteli, tüketicinin talebine uygun, görsel özelliği ön planda olan, nitelikli, katma değeri yüksek, moda, farklı ve yenilikçi ürünlerin tasarımının önem kazanmasına sebep olmuştur. Bu noktadan hareketle kumaş tasarımcıları bazı durumlarda iplik hatalarının hoş bir efekt oluşturabileceğini görmüşler ve planlı hatalar içeren iplik üretim metotlarını araştırmaya başlamışlardır. Bu şekilde üretimleri başlayan fantezi iplikler renk ve/ veya form açısından dekoratif düzgünsüzlük durumunu ifade etmektedir [1-3].

Fantazi iplikler, düz ipliklerin sahip olması istenen düzgünlük, üniformite, homojen büküm ve mukavemet özelliklerinin tersine, üniform bir yapıdan uzak farklı materyal, renk ve büküm varyasyonlarından birine veya birkaçına sahip olan çok değişik, karmaşık yapıda ve neredeyse sınırsız çeşitlilikte olabilen ipliklerdir. Dokuma, triko ve el örgüsü kumaşlar gibi çok çeşitli alanlarda kullanılabilen fantazi iplikler, içerdikleri efektlerle kumaşlara katma değer katarak görsel özelliği ön planda olan yüksek karlılığa ve çeşitliliğe sahip yenilikçi ürünlerin tasarlanıp üretilebilmesine imkân sağlamaktadır [4,5]. Kullanılan hammadde, üretim parametreleri (besleme hızı, büküm ve çekim özellikleri), makineye beslenen materyal özellikleri (farklı iplik, fitil veya bantlar) değiştirilmek suretiyle çok farklı özelliklerde fantezi iplikler elde edilebilmektedir [1,6].

En yaygın fantezi ipliklerden birisi şantuklu ipliklerdir. Şantuklu iplik, eğirme işlemi sırasında iplik lineer yoğunluğunun değiştirilmesiyle şantuk görünüşünün elde edildiği ve özel görünümü nedeniyle farklı alanlarda kullanılan bir çeşit fantezi ipliktir. Karakteristik özelliği, iplik çapında kalınlaşmaların görülmesi olan şantuklu iplikler balıklı iplik olarak da adlandırılmaktadır. (Şekil 1). Özellikle ring iplik eğirme makinesinde üretilen şantuklu iplikler, düz kumaşlara çok değişik görsel etkiler kazandırmakta ve rekabette öne geçmek için iplik üreticisine esneklik sağlamaktadır.

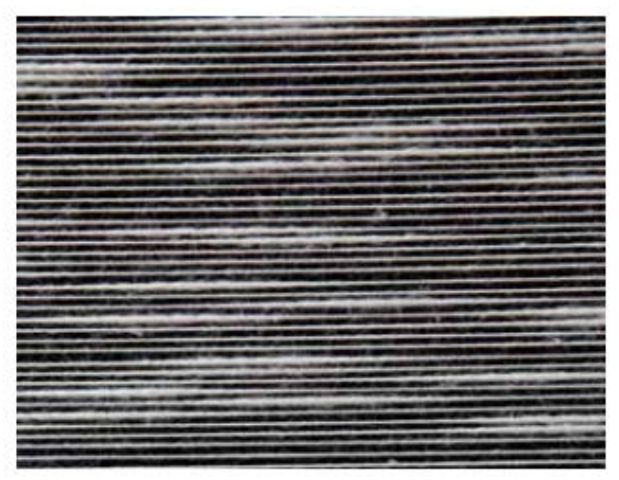

Şekil 1. Şantuk iplik yapısı [7]

İlk olarak pamuklu kumaşlara keten görünümü kazandırılması amacıyla tasarlanan şantuklu iplikler, denim kumaşların ve örme giysilerin dışında gömlek, elbise, pantolon, takım elbise gibi moda tasarım giysilerinde ve ev tekstilinde, perde, kilim, mobilya ve otomobil döşemelik kumaşlarında kullanılmaktadır (Şekil 2). Kullanım alanı bu kadar yaygın olan şantuklu ipliklerin üretiminde kullanılan hammadde tipleri de çok çeşitli olabilmektedir. Denim ve dış giyim endüstrisinde yaygın olarak kullanılmakta olan pamuk, yine dış giyimde yaygın olarak kullanılan viskon ve ev tekstilinde önemli bir yer tutan polyester liflerinden ihtiyaca göre çeşitli numara ve bükümlere sahip şantuklu iplikler üretilmektedir [5]. 


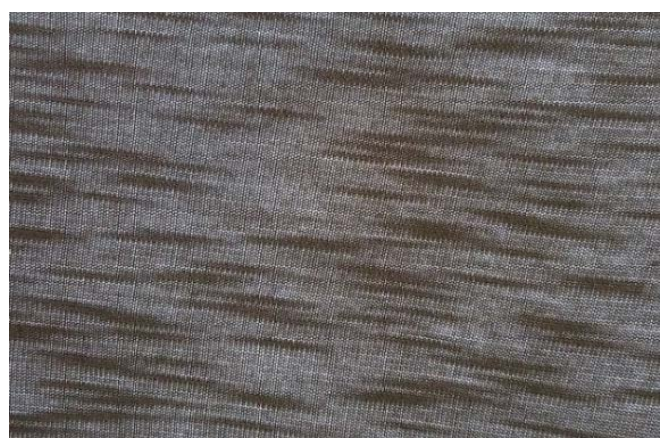

Şekil 2. Şantuklu ipliklerden üretilmiş örme kumaş

\section{2. Şantuklu İplik Üretim Yöntemleri}

Şantuklu iplikler farklı yöntemlerle üretilebilir. Bunları aşağıdaki gibi özetleyebiliriz:

1. En çok kullanılan yöntem ring iplik makinesinde şantuklu iplik üretmektir. Ring iplik makinesinde belli bir iplik numarasında iplik üretimi yapılırken, ön çekim milinin hızı sabit kalmak üzere, istenilen zaman aralıklarında orta ve arka çekim millerinin dönüş hızları eş zamanlı olarak ivmelendirilerek anlık çekim azaltılır ve böylece iplikte kalın yerler oluşturulmaktadır. Şantuklu iplik üretimi süresince uygulanan büküm değeri değişmemektedir.

2. Kesikli lif eğirme makinelerinde değişik boyutlarda lifler karıştırılarak şantuklu iplik üretimi yapılabilmektedir. Örneğin, kamgarn tops bandı içine rastgele dağılmış ştrayhgarn elyaflar karıştırılabilir.

3. Eğirme sisteminde, iki adet temel iplikle birlikte, bükümsüz bir fitilden besleme silindirlerinin ani hareketleri ile periyodik olarak koparılan düz lif demetleri beslenir ve büküm uygulanarak iplik kararlı hale getirilir. Böylece daha açık ve düzenli eğrilmiş şantuklu iplikler elde edilir.

4. İplik eğirme makinesinde çekim bölgesinde ipliği oluşturan malzemenin içine ilave malzeme beslenerek şantuk oluşumu sağlanır. Enjeksiyon metodu olarak bilinen yöntemde sade görünüme sahip şantuklu iplikler yapılabilse de genelde daha abartılı flake ve flam (uzatılmış şantuk) iplikler üretilmektedir. Bu iplikler, uzun ve ağır şantuk efektlerine sahiptir [2]. Enjeksiyon sistemiyle ring iplik makinesinde çok bileşenli şantuklu ipliklerin üretiminde iki kat iplik içine kontrollü fitil enjeksiyonu ile çeşitli renklerde şantuklar üretilebilmektedir [8].

5. Open-end iplik makinesinde de şantuklu iplik üretimi mümkün hale gelmiştir. Rotor iplik makinesinde besleme mili aralıklı olarak ivmelendirilmek suretiyle şantuk oluşumu sağlanmaktadır. Rotor iplik makinelerinde rotor boyu şantuk boyunu sınırlayan bir faktördür. Ayrıca diğer iplik üretim tekniklerinde de (OE friksiyon, Hava-jetli eğirme, Vortex eğirme, vb.) bu tür efektleri oluşturulabilmektedir [2, 9].

6. İçi boş iğ yöntemi ile şantuklu iplik üretimi mümkün olabilmektedir. Ring iplik makinesi benzeri bir çekim sisteminde oluşturulan şantuklar, beslenen öz iplik ve efekt ipliği ile birleştirilerek etrafi içi boş iğden sağılan ince bir filament ile sarılmaktadır. Bu sistemde beslenen şerit, fitil gibi malzemeler ipliğin şantuk bileşenini oluşturmakta, öz iplik ve ince filament sargı ipliği ile yapı bütünlüğü ve mukavemet sağlanmakta, ilave efekt iplikleri ile de görsel etki oluşturulmaktadır [9].

\section{3. Şantuklu İpliklerin Yapısal Özellikleri}

Şantuklu bir iplik kendi içinde 2 farklı yapıdan oluşur. Birincisini ipliğin az büküm almış, yumuşak, daha hacimli, kalın ve parlak gözüken şantuklar oluştururken, ipliğin diğer kısmını daha çok büküm alan ve ince gözüken temel iplik 
meydana getirir. Şantuklar, temel ipliğin kalınlığının 3 - 4 katı kadar olabilmektedir. Yeni gelişmeler ile temel ipliğin \% 480 katı kalınlığa kadar şantuk üretimi mümkün olabilmektedir [5].

Optimum özelliklere sahip ürünler üretmek için fantazi ipliğin yapısal ve geometrik özelliklerinin en uygun şekilde belirlenmesi gerekir [10].

Şantuklu ipliklerin yapısal özelliklerinin tanımlanmasında ve ipliğin kalitesinin kontrolünde kullanılan terimler şöyledir;

- Kütle artışı

- Rampa

- Şantuk uzunluğu

- Şantuk alt uzunluğu / şantuk uzunluk mesafesi

- Şantuk mesafesi

- Şantuk / temel iplik numarası

- $\mathrm{T} / \mathrm{B}$ (top/bottom) oran1

- Popülasyonlar

-

- Kütle artışı: Şantuğun kalınlaşma miktarını gösterir. Temel iplik \% 0 kabul edildiğinde, şantuk temel ipliğin kaç katı kalınlıkta ise kütle artışı (\%) o değer (örn. \%40, \%50, \%60,...) olarak alınır.

- Rampa: Temel iplikten şantuğa, şantuktan temel ipliğe geçişte görülen eğimdir. Şantuktan temel ipliğe geçerken, ince yerlerin ve iplikte zayıf noktaların oluşumunu önlemek ve daha düşük mekanik güç harcamak için rampaların kullanılması önerilmektedir.

- Şantuk uzunluğu: Şantuk uzunluğu şantukta oluşan yamuğun orta tabanına eşittir, yani yamuk yüksekliğinin yarısından (rampaların yarısından) ölçülür.

- Şantuk alt uzunluğu / şantuk uzunluk mesafesi: Şantuk alt uzunluğu, varsayılan yamuğun alt kenarının uzunluğudur. Şantuk uzunluk mesafesi de şantuk mesafesi gibi bir önceki şantuğun sonu ile onu izleyen şantuğun başlangıcı arasındaki mesafedir, ancak yamuğun tabanından ölçülür.

- Şantuk mesafesi: Şantuk mesafesi, bir önceki şantuğun sonu ile onu izleyen şantuğun başlangıcı arasındaki mesafedir, yamuk yüksekliğinin yarısından ölçülmektedir. Tüm şantuk mesafeleri ile tüm şantuk uzunluklarının toplamı, toplam test uzunluğunu verir (Şekil 3).
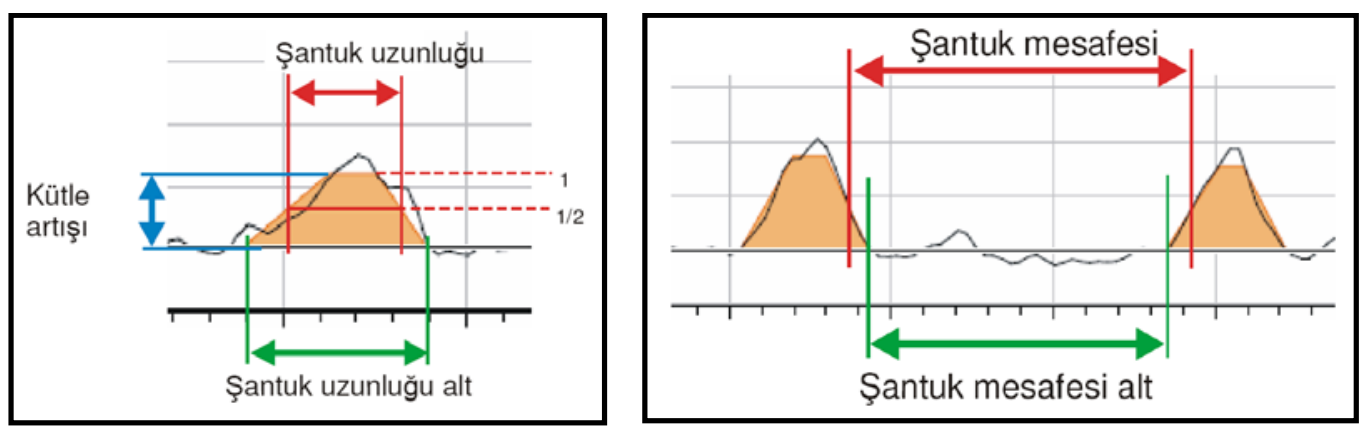

Şekil 3. Şantuk uzunluğu, kütle artışı ve şantuk mesafesi [11].

- Şantuk / temel iplik numarası: Genellikle şantuklu ipliklerin nominal numarası; birim uzunluk için toplam kütlenin ortalama değerinden oluşur. 2 farklı yapıdan oluşan şantuklu iplikte, nominal numarayı meydana getiren 2 farklı 
iplik numarası vardır; Şantuk ve temel iplik numarası. Şantuklu bölgelerde numara, istenen şantuk kalınlığına göre değişmektedir.

- $\quad$ T/B (top/bottom) oranı: T/B oranı (üstten alta şantuk uzunluğu), yamuk formundaki ideal şantuğun üst kenarının tabanına oranıdır. Bu oran, şantuğun rampalarının dikliği ile ilgili bir fikir verir. Eğer iki uzunluk yaklaşık aynı ise bu değer 1 `e yaklaşır. Bu durumda iplikteki rampalar çok diktir ve şantuk oluşumu ani kütle artışı ile gerçekleşmiştir. Sıfıra yaklaşan bir değer ise, üst kenar uzunluğunun yamuğun tabanından çok daha kısa olduğu ve şantuğun oldukça düz bir rampa ile gerçekleştiği anlamındadır.

- Popülasyonlar: Şantuklu iplikler tek tip şantuğa sahip olabileceği gibi bünyesinde iki veya daha fazla şantuk tipine sahip olacak şekilde tasarlanabilmektedir. Şantuklu iplik içinde her bir farklı yapıdaki (kütle artışı, şantuk uzunluğu ya da her ikisinin farklı olduğu) şantuk, bir popülasyonu meydana getirmektedir (Şekil 4) [11, 12].

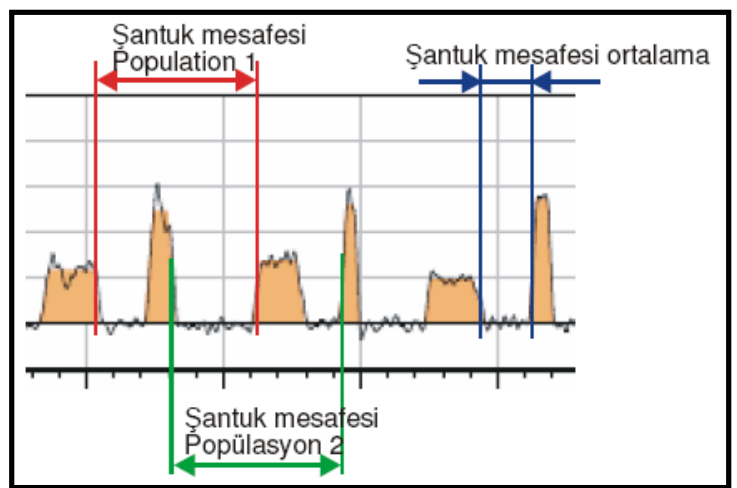

Şekil 4. İki popülasyonlu şantuk ipliği için şantuk mesafesi (Edalat, 2007).

\section{4. Şantuklu İpliklerin Sınıflandırılması}

Şantuklu iplikler yapısal olarak $2 ` y e$ ayrılır;

1. Zemin şantuklu iplikler

- Basit şantuklu iplikler (basic slub)

- Değişken numaralı şantuklu iplikler (multi-count, MC)

- Değişken bükümlü şantuklu iplikler (multi-twist, MT)

2. Çok bileşenli şantuklu iplikler

Zemin şantuklu ipliklerde; iplik eğirme sistemlerinde tek kat iplik üretilirken çekimi değiştirmek yoluyla temel ipliğin parçası olarak şantuklu kısımların oluşturulması şeklinde elde edilmektedir. Zemin şantuklu ipliklerde şantuğun malzemesi ile temel ipliğin malzemesi aynıdır. Çok bileşenli şantuklu ipliklerde büküm veya eğirme makinelerinde değişik özelliklerde eğrilmiş iplik, filament, fitil, şerit vb. malzemelerin birleştirilmesi ve bunların içinde fitil veya şeridin şantuk oluşturacak şekilde kesik kesik beslenmesi sağlanarak bükülmesi yoluyla elde edilmektedir [13].

Basit şantuklu iplikler (basic slub, temel şantuk): Üretim süresince büküm sabittir, iplik numarası değişkendir. 
Bu ipliklerde $T / "=\alpha_{e} \sqrt{N_{e}}$ formülüne göre, büküm ( T’”) sabit, büküm katsayısı ( $\left.\alpha_{\mathrm{e}}\right)$ ve iplik numarası (Ne) değişkendir (Şekil 5).

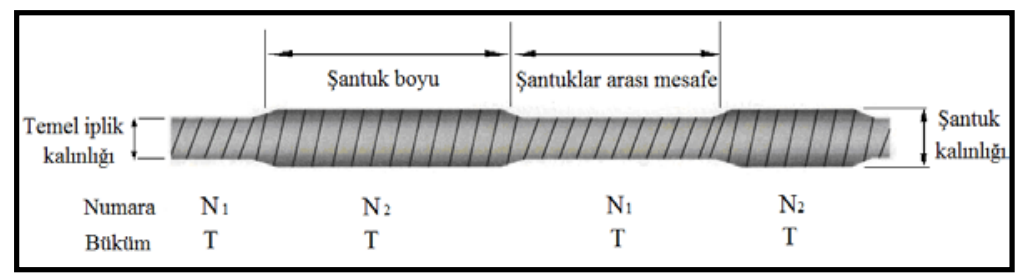

Şekil 5. Basit şantuklu iplik yapısı.

Değişken numaralı (multi-count) şantuklu iplikler: Farklı kalınlık ve farklı bükümdeki iplik bölgelerinin kombinasyonu ile oluşan iplik türüdür. İplik numarası ve büküm değeri iplik uzunluğu boyunca en az 2 m. ’lik belli mesafelerde değişkendir. İplik numarasına uygun olarak büküm değeri ( $\left.\mathrm{T}^{\prime \prime}\right)$ değiştirilmektedir. Genellikle büküm katsayısı $\left(\alpha_{e}\right)$ tüm iplik boyunca aynıdır, yani her bölge kalınlığına göre büküme sahiptir (Şekil 6). İplik numarası ile bükümünü aynı anda değiştirmek için tüm çekim milleri servo-motor ile eşzamanlı olarak kontrol edilmektedir [5,9].

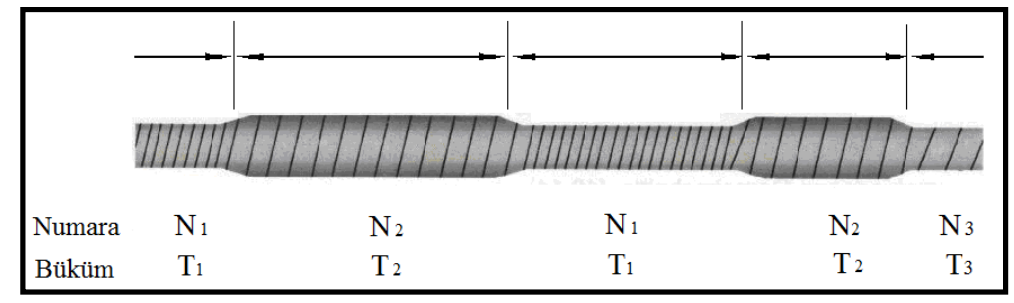

Şekil 6. Değişken numaralı şantuklu iplik yapısı.

Günümüzde denim kumaşların üretilmesinde MC ipliklere büyük talep bulunmaktadır. Uygulamada MC ipliklerde, tekrar eden 2- 5 farklı iplik numarası oluşturulur. Farklı numaraya sahip iplik bölümlerinin uzunluğu 0,5m. ile 5m. arasındadır. Pantolonların bacak kısmında ve üst giysilerin kol bölgesindeki denim kumaşlarda kısa boyda efektler ilginç olmaktadır. Daha nadir olarak üretilen uzun iplik efektleri ise ev tekstili alanında tercih edilmektedir [14].

- Değişken bükümlü (multi-twist) şantuklu iplikler: İplik numarası sabit, büküm değeri ( $\quad$ (T") ve büküm katsayısı $\left(\alpha_{\mathrm{e}}\right)$ belli aralıklarda değişken olan ipliklerdir (Şekil 7). Büküm varyasyonu, sadece ipliğin uzun kısımlarında fark edilebilmektedir. Büküm değişimi için iplikte en kısa uzunluk 500 mm., maksimum büküm varyasyonu ise \%20 olmalıdır. En az 100 mm. olacak şekilde uzun rampaların kullanılması önerilmektedir. Değişken bükümlü ipliklerde kütle artışı gerçekleşmediğinden, iplikte kalın yerler oluşmaz, ancak aynı iplik üzerinde farklı değerlerde bükülmüş bölgeler oluşur. İplik boyandığında farklı bükümlü yerlerde farklı miktarda boya alımı olacağından parlaklık ve renk tonu farklılıkları görülür. Böylece elde edilen efektler ile farklı ve özel bir kumaş görünümü oluşturulabilir. MT iplikler değişken numaralı iplik üretebilen sistemlerde üretilebilmektedir. 
Nevşehir Bilim ve Teknoloji Dergisi (2019), 8(1) 33-41

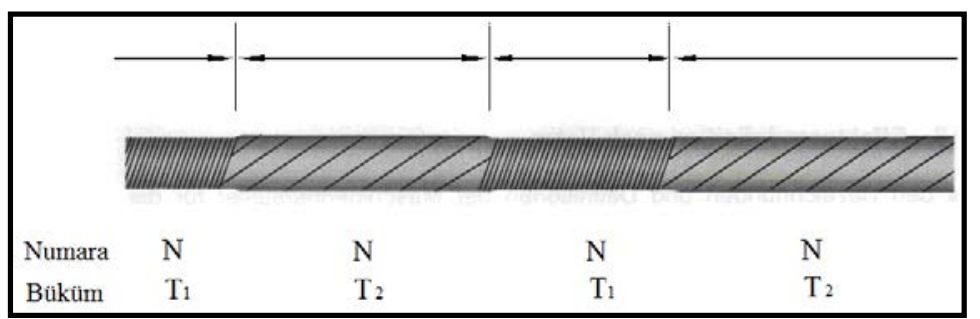

Şekil 7. Değişken bükümlü şantuklu iplik yapısı.

Değişken numaralı ve değişken bükümlü ipliklerin bir araya getirilip aynı iplik üzerinde oluşturulmasıyla da kombine iplikler elde edilir [5].

\section{5. Şantuklu İpliklerde Kalite Kontrol}

Şantuklu ipliklerin tüm dünyada kullanımının artması ile kalite kontrolü ve iplik standartlarının belirlenmesi önemli hale gelmiştir. Şantuklu ipliklerin kalitesinin ölçülmesi; partiler arasında efekt farkı olmayacak şekilde yeniden üretilebilirlik, makine ayarlarını karşılaştırabilmek, üretimin istenildiği gibi gidip gitmediğini görebilmek açısından kalite kontrol işlemlerinin sağlanması bakımından gereklidir.

Şantuklu ipliklerde oluşabilecek hatalar şunlardır:

- Uzun bir mesafe boyunca eksik şantuklar

- Şantukların kütle artışının çok düşük olduğu, doğru bir şekilde üretilmeyen şantuklar

- Şantuk uzunluğu ve kütle artışı gibi belirlenen spesifikasyonları karşılamayan şantuklar

- İplik karışmaları

- Periyodik hatalar

- Desen tekrarı [15].

Şantuklu ipliklerin kalite kontrolü yapılırken, bu ipliklerin mekanik özelliklerinin yanı sıra yapısal özellikleri de önemlidir. Bu ipliklerde daha çok aşağıdaki kontroller yapılmaktadır:

Mukavemet/Uzama; Şantuklu ipliklerde mukavemet düz iplikler için kullanılan mevcut ölçüm cihazları ile ölçülebilmektedir. Ancak şantuklu ipliklerde şantuklu kısımların varlığından dolayı değişim katsayısının yüksek olması beklendiği için daha fazla sayıda ölçüm yapılması önerilmektedir. Şantuklu ipliklerin mukavemeti ölçülürken, şantuklu ve temel iplik kısımlarındaki mukavemet farklılıkları nedeniyle kopma kuvvetinin ortalama iplik numarasına bölünmesi ile elde edilen mukavemet değeri (cN/tex) yerine doğrudan kopma kuvvetinin (cN) kullanılması önerilmektedir [15].

Düzgünsüzlük; Şantuklu ipliklerde düzgünsüzlük ölçümü düz ipliklere göre daha zordur. 2000`li y1llarda şantuklu ipliklerin üretimindeki çok hızlı artışla birlikte bu ipliklerin kalitesinin ölçümü için de yeni sistemler geliştirilmiştir. Uster ${ }^{\circledR}$ Tester 5 cihazının bir yazılım opsiyonu olan “Fantazi İplik Profili” (Fancy Yarn Module) Haziran 2007` de pazara tanıtılmıştır. Son geliştirilen Uster Tester 6 cihazı da aynı modülü içermektedir. Fantazi İplik Profili, fantazi ipliklerin kapsamlı bir şekilde ölçülebilmesini, şantuklu ipliklerin çeşitli istatistiksel değerler ve grafikler aracılığı ile detaylı analizinin yapılabilmesini sağlamaktadır.

Ölçüm sonucunda ipliğin $\mathrm{CV}_{\mathrm{m}}$ değeri, şantuk uzunluğu, mesafesi, kütle artışı, frekansı gibi tanımlayıcı birçok değer verilerek kullanılan şantuk aparatı ile üretilen iplikte hedeflenen ve gerçekleşen iplik özellikleri kıyaslanabilmektedir. Popülasyon seçilerek oluşturulmuş ölçüm raporunda ise $\mathrm{CV}_{\mathrm{m}}$, dışarıda kalanlar, şantuk ve temel iplik numarası hariç tüm değerlerin yanında sadece popülasyon (P1) içindeki şantuklar göz önünde bulundurularak hesaplanmış sonuçlar verilmektedir. Birden fazla popülasyon olduğunda da (P1, P2, P3, ...) her popülasyon için sonuçlar 


\section{Nevşehir Bilim ve Teknoloji Dergisi (2019), 8(1) 33-41}

ayrı ayrı değerlendirilebilmektedir. Bu şekilde makineler ve partiler arasındaki varyasyon da görülebilmektedir. Ölçüm sonucunda verilen birçok görsel grafik, histogram ve diyagramlar ile şantuk öncesi veya sonrası rahatsız edici herhangi bir kütle azalması olup olmadığı, ipliklerde şantuk dağılımının nasıl gerçekleştiği gibi önemli sorulara yanıt alınabilmektedir. Fantazi İplik Profili’nde ölçüm yapılırken Standart Modül`den ipliğin tüylülülüğü, çap varyasyonu, tüylülük varyasyonu, yoğunluğu, ortalama çap değeri gibi verilere de ulaşılmaktadır. Çap varyasyonu ölçüm sonuçları yüzdesel olarak verilirken, iplik tüylülüğü $1 \mathrm{~cm}$. iplikte bulunan çıkıntı liflerin toplam uzunluğuna karşılık gelen H değeri cinsinden verilmektedir.

Grafiksel değerlendirme kısmında ise kütle diyagramı, sıralama diyagramı, şantuk sıralama saçılım grafiğgi, şantuk frekans saçılım grafiği, sınıflandırma matrisi, 3 boyutlu histogram, şantuk uzunluğu histogramı, şantuk mesafesi histogramı, kütle artışı histogramı, spektrogramlar verilmektedir. Sayısal verilerin ve grafiksel değerlendirmenin dışında iplik sonuçları ve kumaş görüntüsünün korelasyonu için kütle diyagramından yararlanılarak simülasyon gerçekleştirilebilmektedir. Test edilen ipliğin dokuma, örme kumaş hali ve levhadaki görüntüsünün tahmini olarak önceden görülebilmesi mümkün olabilmektedir [11].

\section{Sonuç}

Farklı görsel efektleri ile giyim ve ev tekstil ürünlerinde giderek artan kullanım alanına sahip olan fantazi iplikler içerisinde şantuklu iplikler önemli bir yer tutmaktadır. Karakteristik özelliği, iplik çapında planlı kalınlaşmaların görülmesi olan şantuklu iplikler farklı yöntemlerle üretilebilmektedir. Kütle artışı, şantuk uzunluğu, şantuk mesafesi, şantuk/temel iplik numarası ve popülasyonlar şantuklu ipliğin en önemli yapısal parametreleridir. Bu yapısal parametrelerin kontrolü sürekli olarak aynı efekti sağlayacak şekilde üretimin sağlanması açısından çok önemlidir. Özellikle düzgünsüzlük ölçüm cihazlarında geliştirilen Fantezi İplik Modulu ile tüm yapısal parametreler ölçülebildiği gibi şantuklu ipliklerin çeşitli istatistiksel değerler ve grafikler aracılığı ile detaylı analizinin yapılabilmesini sağlamaktadır.

\section{Teşekkür}

Bu çalışma Ege Üniversitesi 16-MÜH-086 numaralı BAP projesi tarafından desteklenmiştir.

\section{Kaynaklar}

[1] Süpüren G., Özçelik G., Turay A., Özdil N., "Yaygın Olarak Kullanılan Fantazi İplikler ve Özellikleri”, Niğde Tekstil Sempozyumu, Niğde Üniversitesi, 2008.

[2] Gong, R. H. and Wright, R. M., “Fancy yarns Their manufacture and application”, Textile Institute, Woodhead Publishing, 2002.

[3] Petrulyte, S., "Fancy Yarns: Efforts to Methodise, Problems, and New Suggestions", Materials Sclence (Medžlagotyra), ISSN 1392-1320, Vol. 10, No. 1, 85-89, 2004.

[4] Öztekin, M., “Şantuk Kalınlıklarının İplik Mukavemetine Etkisi”, Güncel Gelişmeler Çerçevesinde Tekstil Teknolojileri 4, 2009.

[5] Şamlı,E., “Şantuklu İpliklerde Düzgünsüzlük Ölçümü ve İplik Özelliklerinin İncelenmesi”, Yüksek Lisans Tezi Ege Üniversitesi Fen Bilimleri Enstitüsü, Bornova-İzmir, 2010.

[6] Petrulytè and Petrulis, D., "Forecasting of Structural Parameters of Hollow Spindle Yarns”, Materials Science (Medžlagotyra), Vol. 9, 293-296, 2003.

[7]URL-1:http://www.camozzi-manufacruring.com/sites/default/files/ pages_attach/marzoli_fancy_yarn/marzoli_fancy_yarn_turkish.pdf (Erişim Tarihi: 10 Haziran 2018). 
Nevşehir Bilim ve Teknoloji Dergisi (2019), 8(1) 33-41

[8] Amsler Tex AG, http://www.amslertex.com/injected_frame.htm

[9] İlhan, İ., Babaarslan O. ve Baykal P.D., “Şantuklu İplik Üretim Teknolojisi ve İplik Özellikleri Üzerine Bir Çalışma”, II. Tekstil Makinalart ve Tekstil Teknolojileri Kongresi, Gaziantep, 2007.

[10] Ragaišienè, A., "Influence of Overfeed and Twist on Fancy Yarns $\quad$ Structure”, Materials Science, 15: 2, 2009.

[11] Edalat, S., (2007). Uster Tester 5 Application Report, Measurement of slub yarns, Part 1/Basics, Uster Technologies $\mathrm{AG}$, İsviçre.

[12] Meier S., "Measurement of slub yarns for retailers, garment makers and traders”, Uster Tester 5-S800 Application Report, Uster Technologies AG, İsviçre, 2008.

[13] İlhan İ., "Ring İplik Makinesi İçin Elektronik Kontrollü Şantuk Sisteminin Geliştirilmesi ve Şantuklu İplik Özelliklerinin İncelenmesi”, Çukurova Üniversitesi Fen Bilimleri Enstitüsü, Doktora Tezi, 2010.

[14] Iqbal, S. and Pramanik, P., “Fancy Yarns: Slub \& Multicount”, Indian Textile Journal, 2009. http://www.indiantextilejournal.com/articles

[15] Edalat, S., “Measurement of slub yarns, Part 2/Experience in Mills”, Uster Tester 5 Application Report Uster Technologies AG, İsviçre, 2008. 